\title{
Response to dietary supplementation of mixtures of either selected synbiotic, organic acids or essential oils as growth promoters for growing Japanese quails
}

\author{
A.M. Safwat ${ }^{1}$, M.O. Taher, M. Bahie El-Deen and M. Abd El-Naeem \\ Alexandria University, Faculty of Agriculture (El-Shatby), Poultry Production Department, 21545, Alexandria, Egypt
}

KEY WORDS: carcass yield, growth promoters, intestines, Japanese quails

Received: 27 March 2021

Revised: 23 June 2021

Accepted: 23 June 2021

${ }^{1}$ Corresponding author:

e-mail: assemsafwat2004@yahoo.com

\begin{abstract}
The present study was aimed to compare the efficacy of natural dietary supplementations (either synbiotics, organic acids or essential oils) in promoting productive performance and health status of growing Japanese quails. In total, 840 unsexed quail chicks aged 14 days, were randomly distributed into four groups of 210 birds in seven replicates, 30 birds each. The first group was fed un-supplemented control diet, the other groups were supplemented with: i) a mixture of live Saccharomyces cerevisiae, Bacillus spp. and their cell wall extracts, in addition to $\beta$-glucan and mannan-oligosaccharides as synbiotics; ii) a mixture of formic and propionic acids as organic acids; or iii) a mixture of carvacrol, cinnamaldehyde and capsicum oleoresin as essential oils; at a level of $1,0.5$ and $0.15 \mathrm{~g}$ per kg diet, respectively. It was indicated that birds fed diets supplemented with either examined mixture of essential oils or organic acids had significantly higher body weight and better feed conversion ratio than the control group (by 5.4 and $4.9 \%$, and 10.3 and $8.8 \%$, respectively). It was also revealed that all studied growth promoters significantly increased the abdominal fat percentage. Both groups treated with mixture of either essential oils or organic acids recorded significantly higher villi height and width with lower total bacterial count and Escherichia coli enumeration than the control one. In conclusion, both examined mixtures of either essential oils (with carvacrol, cinnamaldehyde and capsicum oleoresin) or organic acids (formic and propionic acids) could be used in quail diets as organic growth promoters as they enhance growth performance by improving blood parameters and gut health status.
\end{abstract}

\section{Introduction}

Japanese quail has gained special interest in the poultry industry as a good producer of organic meat and eggs for healthy human nutrition (Curry, 2009). In order to promote poultry production, a greater understanding of the relationship between diet and health must be largely achieved through nutritional solutions (Cross et al., 2007). It has become now necessary to search and develop antibiotic alternative compounds with similar economic return, and the production efficiency has to be sustainable in order to be accepted for commercial sector (Collett, 2004).

A variety of products has been developed as alternatives to antibiotic growth promoters that could be supplemented to the poultry feed to enhance productive performance, improve intestinal villus integrity, promote higher nutrient digestibility or reduce the spread of diseases by exerting antimicrobial activity (Griggs and Jacob, 2005; Fascina et al., 2012).

The different beneficial effects of such compounds are depending on their mode of action in the 
host body. Synbiotics (such as mixture of prebiotics including mannan-oligosaccharides or $\beta$-glucan and probiotics containing different Lactobacillus spp., Bifidobacterium bifidum, Streptococcus salivarius spp. and Enterococcus faecium) beneficially alter the intestinal microbiota composition and improve structural histomorphology of the intestinal mucosa providing better intestinal health for the bird to obtain maximum nutrient absorption (Sohail et al., 2012), additionally, $\beta$-glucan and mannanoligosaccharides are well-known as antioxidant and immunocompetent agents (Rageb et al., 2018). Another type of compounds are the organic acids (e.g., formic and propionic acids) that modify the intestinal $\mathrm{pH}$ and reduce the numbers of pathogenic bacteria through cell-wall penetration, in addition to increase acid-tolerant beneficial species such as Lactobacillus spp. and reduce competition for nutrients by the altered microbes (Goodarzi Boroojeni et al., 2014). Meanwhile, essential oils compounds (e.g., cinnamaldehyde, thyme oil, carvacrol or capsaicin) proposed several mechanisms that include antimicrobial activity against pathogens, antioxidant activity, enhancing the function and regeneration of erythrocytes, stimulating carbohydrates and lipids metabolism in addition to their anti-allergenic effects (Jamroz et al., 2003; Sengül et al., 2008; Abd El-Hack et al., 2020; Krauze et al., 2021).

There are some important measurements, beside the productive performance, that evaluate the effects of dietary growth promoter substances on animal health such as studying blood profile (including haematological parameters, protein and lipid profiles as well as liver and kidney functions) which could be used as an indicator for the physiological status and the welfare condition of birds (Moniello et al., 2005), intestinal histopathology and microbial ecology of animals (Incharoen et al., 2010; Abd-Allah and Abdel-Raheem, 2012). There were published several researches with conflicting results regarding the role of natural growth promoters (including probiotics of Saccharomyces cerevisiae and Lactobacillus spp., prebiotics of $\beta$-glucan and mannan-oligosaccharides, formic acid, propionic acid, carvacrol, cinnamaldehyde and capsicum oleoresin) in stimulating poultry performance, as these effects depend on the form and/or source of such compounds, bacterial species to be resisted, animal species and the growth promoter site of action (Hassan et al., 2010; Fascina et al., 2012; Oleforuh-Okoleh et al., 2015); however, the complete information of such compounds on quail performance is still scarce. In this context, an integrated study is required to evaluate different compounds as antibiotic growth promoter alternatives for organic Japanese quail production. In this paper, it was hypothesized that dietary supplementation of either synbiotics, organic acids or essential oils could promote growth through enhancing gut health and physiological status of Japanese quails.

Therefore, the objective of the present study was to evaluate the efficacy of three different mixtures of natural growth promoters: (1. live $S$. cerevisiae, Bacillus spp., $\beta$-glucan and mannan-oligosaccharides as synbiotics; 2 . formic and propionic acids as organic acids; 3 . carvacrol, cinnamaldehyde and capsicum oleoresin as essential oils) in improving productive performance and health status of growing Japanese quails.

\section{Material and methods}

\section{Study site}

The present study was carried out at the Poultry Research Centre, Faculty of Agriculture, Alexandria University, Egypt. Birds were reared in a semi-closed housing system with room temperature between $25-30{ }^{\circ} \mathrm{C}, 55-70 \%$ relative humidity and $11-12 \mathrm{~h}$ of natural photoperiod during the autumn season.

\section{Birds, treatments and experimental design}

A total number of 840 unsexed quails at 14 days of age were randomly distributed into four treatment groups; every treatment contains seven replicates with 30 birds each. Quails had ad libitum access to water and feed during the whole experimental period. Birds were individually weighed weekly throughout 4 weeks of experimental period. Body weight gain (BWG), feed intake (FI) and feed conversion ratio (FCR) were also determined weekly.

Quails were assigned to four experimental diets: 1) the control basal diet (without any supplementation); 2) basal diet supplemented with $1 \mathrm{~g}$ synbiotics/kg; 3) basal diet supplemented with $0.5 \mathrm{~g}$ organic acids/kg; and 4) basal diet supplemented with $0.15 \mathrm{~g}$ essential oils $/ \mathrm{kg}$. The studied feed supplementations were added to experimental diets during the ingredient mixing process. The experimental diets were prepared daily prior to feeding in order to avoid evaporation or degradation of the studied feed additives. Birds were kept under high standard hygiene and careful management without antibiotic treatments during the whole experimental period. However, a coccidiostat was incorporated in all experimental diets. 
Table 1. Composition and chemical analysis of the experimental basal diet

\begin{tabular}{|c|c|}
\hline Indices & Basal diet \\
\hline \multicolumn{2}{|l|}{ Ingredients, \% } \\
\hline yellow maize & 56.00 \\
\hline soyabean meal (47\%) & 33.50 \\
\hline maize gluten meal $(60 \%)$ & 5.00 \\
\hline soyabean oil & 1.40 \\
\hline limestone & 1.50 \\
\hline mono-calcium phosphate & 1.30 \\
\hline salt & 0.37 \\
\hline vitamin and mineral premix ${ }^{1}$ & 0.30 \\
\hline methionine & 0.27 \\
\hline lysine & 0.23 \\
\hline threonine & 0.08 \\
\hline anti-coccidia & 0.05 \\
\hline \multicolumn{2}{|l|}{ Chemical analysis ${ }^{2}$} \\
\hline $\mathrm{ME}, \mathrm{kcal} / \mathrm{kg}$ & 3000 \\
\hline crude protein, $\%$ & 23 \\
\hline ether extract, \% & 4.3 \\
\hline crude fibre, \% & 3.2 \\
\hline ash content, \% & 4.8 \\
\hline \multicolumn{2}{|c|}{$\begin{array}{l}{ }^{1} \text { supplied each } \mathrm{kg} \text { of complete feed: IU: vit. A } 4500 \text {, vit. D } 1000 \text {, } \\
\text { vit. E } 25 \text {; mg: vit. } B_{12} 0.02 \text {, menadione } 1.5 \text {, riboflavin } 3 \text {, thiamine } 1.5 \text {, } \\
\text { pantothenic acid } 5 \text {, niacin } 20 \text {, choline } 150 \text {, folic acid } 0.5 \text {, biotin } 0.5 \text {, } \\
\text { pyridoxine } 2.5 \text {, manganese } 60 \text {, zinc } 40 \text {, iron } 80 \text {, copper } 8 \text {, } \\
\text { selenium } 0.2 \text {, iodine } 0.8 \text {, cobalt } 0.4{ }^{2} \text { calculated on dry matter basis; } \\
\text { ME - metabolizable energy }\end{array}$} \\
\hline
\end{tabular}

The basal diet (Table 1) was formulated to meet all nutritional requirements of growing Japanese quails according to Akanbi and Kabir (2019).

\section{The identification of studied growth promoters}

Growth promoters used in the experiment were purchased from veterinary medical companies at the Egyptian local market. Each growth promoter was supplemented with the recommended level indicated by the producing company.

Synbiotics. Each $1.0 \mathrm{~kg}$ of the used synbiotic (Organotic Dry ${ }^{\circledR}$, Organic Chemical Solutions, L.L.C., Oakwood, GA, USA) contains: live S. cerevisiae (1 billion CFU per g), $100.0 \mathrm{~g}$; Bacillus subtilis cell wall extract, $50.0 \mathrm{~g}$; Bacillus licheniformis cell wall extract, $50.0 \mathrm{~g}$; $\beta$-glucan, $11.7 \mathrm{~g}$; mannan-oligosaccharides, $9.2 \mathrm{~g}$; saponin, $5.6 \mathrm{~g}$; live B. subtilis (100 $000 \mathrm{CFU}$ per g), $5.0 \mathrm{~g}$; live $B$. licheniformis (100 $000 \mathrm{CFU}$ per $\mathrm{g}$ ), $5.0 \mathrm{~g}$; silica (carrier), up to $1.0 \mathrm{~kg}$.

Organic acids. The composition of the studied organic acids mixture (bio-mold ${ }^{\circledR}$, Lohne, Germany) was formic acid (85\%), 16\%; propionic acid (99\%), $41 \%$; carrier: vermiculite, $43 \%$.

Essential oils. The composition of the studied essential oils mixture $\left(\right.$ Xtract $^{\mathbb{}}$, Pancosma, Rolle, Switzerland) was as follow: carvacrol, $5 \%$; cinnamaldehyde, $3 \%$; capsicum oleoresin, $2 \%$.

\section{Blood collection and haemato-biochemical analyses}

At the end of the experiment, blood samples (about $2 \mathrm{ml}$ ) were collected from 21 quails per each treatment, from the wing vein for haemato-biochemical analysis. Heparin was used as anticoagulation; however, a part of samples was kept without heparin for serum separation. Non-coagulated blood was divided into two parts. The first part was used shortly after collection for estimating complete blood count, where the second part was used to obtain plasma after separation. Plasma or serum was immediately centrifuged at $3000 \mathrm{rpm}$ (rotation per minute) for $15 \mathrm{~min}$. The clear serum samples were carefully drawn and transferred to Eppendorf tubes and stored at $-20{ }^{\circ} \mathrm{C}$ in the deep freezer until the time of chemical determinations. Red blood cells (RBCs) were counted, haemoglobin $(\mathrm{Hb})$ concentration and packed cells volume (PCV) were measured according to Feldman et al. (2000) and Provan et al. (2004), respectively. Serum total protein, albumin, glucose, total lipids, triglyceride, cholesterol, uric acid and creatinine concentrations were determined calorimetrically on a Hitachi 901 spectrophotometer (Hitachi, Tokyo, Japan) using specific kits obtained from Sentinel Diagnostics (Milano, Italy) or CAL-TECH Diagnostics, Inc. (Chino, CA, USA) according to kits manufacturers' recommendations.

\section{Slaughter traits}

At the end of the experiment (42 day of age), 21 quails per each treatment around the average weight were randomly selected for studying slaughter traits. The assigned birds were individually weighed as pre-slaughtering weight then slaughtered and defeathered. The empty carcass, liver, gizzard, abdominal fat and small intestine weights were separately weighted and proportioned to the live pre-slaughtering weight. All the experimental procedures employed were ethically reviewed and approved by Institutional Animal Care and Use Committee (IACUC) of Alexandria University (Egypt); with reference number: AU08191217354.

\section{Intestinal histomorphology}

The tissue samples from jejunum were collected from the slaughtered birds and fixed, after flushing with distilled water, in $10 \%$ neutral buffered formalin saline preparing to histological determinations. The fixed specimens were processed through the conventional paraffin embedding technique (dehydration through ascending grades of ethanol, clearing in xylene and embedding in paraffin wax at $60{ }^{\circ} \mathrm{C}$ ). 
Paraffin blocks were as 5 microns thick sections. Serial sections $(5 \mu \mathrm{m})$ were cut and stained with haematoxylin and eosin (H\&E) according to the method described by Bancroft and Layton (2013). For villus measurements, the distance from the tip of the villus to the villus crypt junction represents villus height, while villus width was estimated in the middle of villus height and the numbers of villi cross sections from each intestinal segment were counted within the specific area.

\section{Microbiological assessment of intestinal contents}

Samples of small intestine and caeca content were collected from the slaughtered birds for microbiological determination. The collected samples were immediately stored at $-20{ }^{\circ} \mathrm{C}$ until all subsequent microbiological analyses. Dilutions were plated on duplicate selective agar media for enumeration of target bacterial groups. Total bacterial count, Lactobacillus and E. coli were enumerated using the methods described by Baurhoo et al. (2007). Total bacterial counts were enumerated on nutrient agar after aerobic incubation for $24 \mathrm{~h}$ at $37^{\circ} \mathrm{C}$. For Lactobacillus, deMan, Rogosa and Sharpe (MRS) agar was used; the plates were incubated in $5 \% \mathrm{CO}_{2}$ for 48 h. Escherichia coli Mac Conkey agar plates were incubated for $24 \mathrm{~h}$ at $37{ }^{\circ} \mathrm{C}$ under aerobic conditions as red colonies. Bacteria were enumerated by a visual count of colonies using the best replicate set from dilutions that resulted in 30 to 300 colonies per plate. All results were expressed as colony-forming units (CFU) per gram of caecal and intestinal content.

\section{Statistical analysis}

Data were subjected to analysis of variance, using the General Liner Model (GLM) procedure of a SAS programme 9.4 (SAS Institute, Cary, NC, USA). The significant tests for the differences between each two means for any studied trait were done according to Duncan (1955). Additionally, linear contrasts were used to compare between the control group vs the average of dietary growth promoters supplemented treatments. Treatment effects were considered significant at $P \leq 0.05$.

As some values in the intestinal microbial count were not detectable, it was preferred to compare the values of intestinal microbiota depending on just the numerical values using a descriptive approach (without performing a statistical analysis). That was found in some researches such as Lin et al. (2013) and Talazadeh et al. (2017).

\section{Results}

\section{Performance traits}

The performance traits of growing quails affected by different dietary growth promoters are presented in Table 2. At the beginning of the experiment, the allotment was correctly performed since the initial live weights were identical among the different treated groups $(0.043 \pm 0.008 \mathrm{~kg}$ on average $)$. With the progress in age and feeding dietary treatments, the groups supplemented with essential oils and organic acids recoded the highest $(P=0.0001)$ final BW (5.4 and $4.9 \%$ higher than those of control group). Also, birds from synbiotics group had higher final BW than control group, but it was lower than in essential oils and organic acids groups. Similarly, BWG was higher by 6.8 and $6.17 \%$ in essential oils and organic acids groups than in the control group, respectively; whereas BWG of birds from synbiotics group was higher than in control group but lower than in essential oils group. Quails treated with essential oils had the lowest FI value with a decrease of $4.5 \%$ than the control group, which significantly consumed the highest amount of feed. It is worthy to note that the overall individual consumption of the studied growth promoters was $0.53,0.26$ and $0.08 \mathrm{~g} / \mathrm{bird}$ of examined synbiotics, organic acid and essential oil products, respectively. Birds fed diets supplemented with either essential oils or organic acids had the best FCR $(P=0.0001)$, while the control group had the worst FCR value. The percentages of FCR improvement for such treated groups compared to control group were 10.3 and $8.8 \%$, respectively.

\section{Blood constituents}

Data presented in Table 3 revealed that the group supplemented with essential oils mixture had the highest RBCs value $(P<0.05)$ followed by the group supplemented with organic acids mixture when compared to the control group, which had the lowest value of RBCs. Similarly, the group supplemented with the essential oils mixture had significantly the highest $\mathrm{Hb}$ value compared to those fed the control group. Moreover, the group supplemented with the essential oils mixture had the highest PCV value $(P<0.05)$ followed by the group supplemented with synbiotics when compared to those of the control group, which had the lowest PCV value.

Although, values of total protein did not significantly differ as affected by studied dietary treatments; the control group had the highest albumin 
Table 2. Effect of dietary supplementation of examined synbiotics, organic acids and essential oils on performance traits of the Japanese quail

\begin{tabular}{|c|c|c|c|c|c|c|c|c|}
\hline \multirow{2}{*}{ Indices } & \multicolumn{4}{|c|}{ Treatment $^{1}$} & \multirow{2}{*}{ SEM } & \multirow{2}{*}{$P$-value } & \multicolumn{2}{|c|}{ Contrast control vs treatments } \\
\hline & control & synbiotics & organic & essential oils & & & mean & $P$-value \\
\hline Initial weight, $\mathrm{kg}$ & 0.042 & 0.043 & 0.044 & 0.043 & 0.008 & 0.431 & 0.043 & 0.101 \\
\hline Final weight, $\mathrm{kg}$ & $0.205^{c}$ & $0.211^{b}$ & $0.215^{a}$ & $0.216^{a}$ & 0.021 & 0.0001 & 0.212 & 0.0001 \\
\hline Body weight gain, $\mathrm{kg}$ & $0.162^{c}$ & $0.168^{b}$ & $0.172^{\mathrm{ab}}$ & $0.173^{\mathrm{a}}$ & 0.023 & 0.0001 & 0.169 & 0.0001 \\
\hline Feed intake, $\mathrm{kg}$ & $0.535^{\mathrm{a}}$ & $0.531^{\mathrm{b}}$ & $0.516^{c}$ & $0.511^{d}$ & 0.022 & 0.0001 & 0.523 & 0.0001 \\
\hline Feed conversion ratio, kg/kg & $3.29^{a}$ & $3.16^{b}$ & $3.00^{c}$ & $2.95^{c}$ & 0.21 & 0.0001 & 3.10 & 0.0001 \\
\hline
\end{tabular}

${ }^{1}$ treatments: control - un-supplemented basal diet; synbiotics - basal diet supplemented with a mixture of live Saccharomyces cerevisiae, Bacillus spp. and their cell wall extracts, in addition to $\beta$-glucan and mannan-oligosaccharides at a dose of $1 \mathrm{~g} / \mathrm{kg}$; organic acids - basal diet supplemented with a mixture of formic and propionic acids at a dose of $0.5 \mathrm{~g} / \mathrm{kg}$; essential oils - basal diet supplemented with a mixture of carvacrol, cinnamaldehyde, and capsicum oleoresin at a dose of $0.15 \mathrm{~g} / \mathrm{kg}$; SEM - standard error of the mean; ${ }^{\text {a-d }}$ - means within the same row with different superscripts are significantly different at $P<0.05$

Table 3. Effect of dietary supplementation of examined synbiotics, organic acids and essential oils on blood parameters of the Japanese quail at 42 day of age

\begin{tabular}{|c|c|c|c|c|c|c|c|c|}
\hline \multirow{2}{*}{ Indices } & \multicolumn{4}{|c|}{ Treatment $^{1}$} & \multirow{2}{*}{ SEM } & \multirow{2}{*}{$P$-value } & \multicolumn{2}{|c|}{ Contrast control vs treatments } \\
\hline & control & synbiotics & \multicolumn{2}{|c|}{ organic acids essential oils } & & & mean & $P$-value \\
\hline \multicolumn{9}{|c|}{ Haematological parameters } \\
\hline $\mathrm{RBCs}, 10^{6} / \mathrm{mm}^{3}$ & $3.11^{\mathrm{c}}$ & $3.16^{c}$ & $3.31^{\mathrm{b}}$ & $3.72^{\mathrm{a}}$ & 0.27 & 0.0053 & 3.33 & 0.0003 \\
\hline $\mathrm{Hb}, \mathrm{g} / \mathrm{dl}$ & $16.31^{b}$ & $16.81^{b}$ & $17.51^{\mathrm{ab}}$ & $19.01^{\mathrm{a}}$ & 1.29 & 0.0124 & 17.42 & 0.001 \\
\hline PCV, \% & $48.96^{c}$ & $59.63^{\mathrm{ab}}$ & $53.85^{\mathrm{bc}}$ & $62.80^{\mathrm{a}}$ & 5.64 & 0.0030 & 56.48 & 0.0023 \\
\hline \multicolumn{9}{|c|}{ Biochemical parameters } \\
\hline $\mathrm{TP}, \mathrm{g} / \mathrm{dl}$ & 3.21 & 3.50 & 3.69 & 3.44 & 0.43 & 0.31 & 3.46 & 0.151 \\
\hline Alb, g/dl & $1.30^{\mathrm{a}}$ & $0.77^{c}$ & $0.93^{b}$ & $0.95^{b}$ & 0.41 & 0.013 & 0.99 & 0.025 \\
\hline Glo, g/dl & $1.91^{\mathrm{b}}$ & $2.73^{a}$ & $2.76^{a}$ & $2.49^{\mathrm{ab}}$ & 0.56 & 0.0463 & 2.47 & 0.010 \\
\hline Glu, mmol/l & 11.91 & 11.15 & 13.41 & 11.02 & 2.03 & 0.20 & 11.87 & 0.951 \\
\hline TLp, g/l & $4.15^{d}$ & $4.78^{c}$ & $5.18^{b}$ & $5.55^{\mathrm{a}}$ & 0.61 & 0.019 & 4.15 & 0.015 \\
\hline $\mathrm{TG}, \mathrm{mmol} / \mathrm{l}$ & $2.11^{b}$ & $2.36^{b}$ & $2.99^{a}$ & $2.80^{\mathrm{a}}$ & 0.43 & 0.001 & 2.56 & 0.014 \\
\hline $\mathrm{TC}, \mathrm{mmol} / \mathrm{l}$ & 5.85 & 5.31 & 6.28 & 5.28 & 1.10 & 0.46 & 5.68 & 0.694 \\
\hline $\mathrm{UA}, \mu \mathrm{mol} / /$ & 531.75 & 508.55 & 562.09 & 508.55 & 114.20 & 0.828 & 528.18 & 0.915 \\
\hline CREAT, $\mu \mathrm{mol} / \mathrm{l}$ & 57.46 & 59.23 & 56.58 & 58.34 & 7.96 & 0.958 & 58.17 & 0.928 \\
\hline
\end{tabular}

${ }^{1}$ treatments: control - un-supplemented basal diet; synbiotics - basal diet supplemented with a mixture of live Saccharomyces cerevisiae, Bacillus spp. and their cell wall extracts, in addition to $\beta$-glucan and mannan-oligosaccharides at a dose of $1 \mathrm{~g} / \mathrm{kg}$; organic acids - basal diet supplemented with a mixture of formic and propionic acids at a dose of $0.5 \mathrm{~g} / \mathrm{kg}$; essential oils - basal diet supplemented with a mixture of carvacrol, cinnamaldehyde and capsicum oleoresin at a dose of $0.15 \mathrm{~g} / \mathrm{kg}$; RBCs - red blood cells, $\mathrm{Hb}$ - haemoglobin, PCV - packed cell volume, TP - total protein, Alb - albumin, Glo - globulin, Glu - glucose, TLp - total lipid, TG - triglyceride, TC - total cholesterol, UA - ureic acid, CREAT - creatinine, SEM - standard error of the mean; ${ }^{a-d}$ - means within the same row with different superscripts are significantly different at $P<0.05$

value $(P=0.013)$ in comparison to the other treated groups, whereas the group fed synbiotics supplemented diet recorded the lowest value with around $41 \%$ decrement than the control group. On the contrary, the groups supplemented with synbiotics and organic acids mixture had significantly higher globulin values than the control group, which had the lowest globulin value.

There was not any significant difference $(P>0.05)$ among the experimental groups regarding glucose level.

The highest total lipid concentration $(P=0.019)$ was observed in birds fed diet supplemented with essential oils followed by the organic acids group (with 33.7 and $24.8 \%$ increment than the control group, respectively). The same trend was obtained with triglyceride levels, where the groups fed essential oils or organic acids had significantly the highest triglyceride concentration (with 32.7 and $41.7 \%$, respectively higher than the control group). Favourably, the higher plasma total lipids and triglyceride concentration for essential oils and organic acids treatments did not increase the cholesterol level $(P>0.05)$.

The obtained results indicated that plasma uric acid and creatinine concentrations were not significantly affected by different growth promoters. 


\section{Carcass and internal organs traits}

Statistical analysis revealed a significant increment in carcass weight for quails supplemented with essential oils mixture in comparison to those of the control group (Table 4). The carcass yield percentage as well as all relative weights of internal organs (liver, gizzard, small intestine) did not differ $(P>0.05)$ among the experimental groups except for abdominal fat which significantly increased in all growth promoters' treatments in comparison to the control group with 65,65 and $86 \%$ increment for synbiotics, organic acids and essential oils treatments, respectively. essential oils and organic acids had significantly the highest values of villi width, but the group fed diet supplemented with synbiotics had the lowest one $(P=0.04)$. Although, the comparison between the control group and the average of the studied growth promoters' groups did not detect statistical difference regarding the villi width parameter $(P=0.370)$.

\section{Intestinal microbial count}

Supplementing quails' diet with either essential oils or organic acids treatments decreased the total bacterial count in ileum and caecum content by around 49 or $59 \%$ compared to that of the control

Table 4. Effect of dietary supplementation of examined synbiotics, organic acids and essential oils on carcass characteristics of the Japanese quail at 42 day of age

\begin{tabular}{|c|c|c|c|c|c|c|c|c|}
\hline \multirow{2}{*}{ Traits } & \multicolumn{4}{|c|}{ Treatment $^{1}$} & \multirow{2}{*}{ SEM } & \multirow{2}{*}{$P$-value } & \multicolumn{2}{|c|}{ Contrast control vs treatments } \\
\hline & control & synbiotics & organic acids & essential oils & & & mean & $P$-value \\
\hline Carcass weight, $\mathrm{g}$ & $149.33^{b}$ & $154.33^{\mathrm{ab}}$ & $159.06^{\mathrm{ab}}$ & $161.97^{\mathrm{a}}$ & 3.42 & 0.048 & 156.17 & 0.024 \\
\hline Carcass yield, $\%$ & 71.50 & 70.64 & 69.40 & 69.71 & 3.07 & 0.17 & 70.32 & 0.104 \\
\hline Liver, \% & 2.09 & 2.36 & 2.23 & 2.37 & 0.41 & 0.16 & 2.26 & 0.103 \\
\hline Gizzard, \% & 2.15 & 1.94 & 1.98 & 2.04 & 0.25 & 0.37 & 2.03 & 0.110 \\
\hline Abdominal fat, $\%$ & $0.43^{b}$ & $0.71^{\mathrm{a}}$ & $0.71^{\mathrm{a}}$ & $0.80^{\mathrm{a}}$ & 0.33 & 0.018 & 0.64 & 0.002 \\
\hline Small intestine, $\%$ & 3.33 & 3.62 & 3.48 & 3.88 & 0.79 & 0.22 & 3.58 & 0.144 \\
\hline
\end{tabular}

${ }^{1}$ treatments: control - un-supplemented basal diet; synbiotics - basal diet supplemented with a mixture of live Saccharomyces cerevisiae, Bacillus spp. and their cell wall extracts, in addition to $\beta$-glucan and mannan-oligosaccharides at a dose of $1 \mathrm{~g} / \mathrm{kg}$; organic acids - basal diet supplemented with a mixture of formic and propionic acids at a dose of $0.5 \mathrm{~g} / \mathrm{kg}$; essential oils - basal diet supplemented with a mixture of carvacrol, cinnamaldehyde and capsicum oleoresin at a dose of $0.15 \mathrm{~g} / \mathrm{kg}$; SEM - standard error of the mean; ${ }^{\mathrm{a}-\mathrm{b}}$ - means within the same row with different superscripts are significantly different at $P<0.05$

\section{Histological examinations}

The highest villi height in jejunum samples were observed in birds fed diet containing essential oils with $103.7 \%$ increment than in the control group in which villi height was the lowest (Table 5). Likewise, the number of villi counted in the jejunum area for the essential oils group was nearly two times higher than the number recorded for the control group. Also, in organic acids and synbiotic group the number of villi was higher than in control group. Whereas, both groups fed group, respectively (Table 6). The highest $E$. coli count was observed in the control birds $\left(23 \times 10^{6}\right)$ followed by the synbiotics treatment $\left(6.2 \times 10^{6}\right)$, while the samples of either organic acids or essential oils supplemented groups recorded almost no charge in E. coli bacteria count. All growth promoters' treatments increased Lactobacillus spp. count in the intestinal content samples by around 20.5, 15.9 and $38.6 \%$ for synbiotics, organic acids and essential oils, respectively in comparison to birds receiving the control diet.

Table 5. Effect of dietary supplementation of examined synbiotics, organic acids and essential oils on jejunum histological parameters of the Japanese quail at 42 day of age

\begin{tabular}{|c|c|c|c|c|c|c|c|c|}
\hline \multirow{2}{*}{ Parameters } & \multicolumn{4}{|c|}{ Treatments $^{1}$} & \multirow{2}{*}{ SEM } & \multirow{2}{*}{$P$-value } & \multicolumn{2}{|c|}{ Contrast control vs treatments } \\
\hline & control & synbiotics & organic acids & essential oils & & & mean & $P$-value \\
\hline Villi height, mm & $1.08^{d}$ & $1.53^{c}$ & $1.81^{\mathrm{b}}$ & $2.20^{\mathrm{a}}$ & 0.39 & 0.0001 & 1.66 & 0.0001 \\
\hline Villi width, $\mu \mathrm{m}$ & $191.00^{\mathrm{ab}}$ & $183.70^{\mathrm{b}}$ & $197.40^{\mathrm{a}}$ & $194.40^{\mathrm{a}}$ & 43.76 & 0.04 & 180.13 & 0.37 \\
\hline Number of villi & $30.90^{c}$ & $34.00^{b}$ & $39.80^{\mathrm{b}}$ & $62.00^{\mathrm{a}}$ & 7.77 & 0.0001 & 41.68 & 0.0001 \\
\hline
\end{tabular}

${ }^{1}$ treatments: control - un-supplemented basal diet; synbiotics - basal diet supplemented with a mixture of live Saccharomyces cerevisiae, Bacillus spp. and their cell wall extracts, in addition to $\beta$-glucan and mannan-oligosaccharides at a dose of $1 \mathrm{~g} / \mathrm{kg}$; organic acids - basal diet supplemented with a mixture of formic and propionic acids at a dose of $0.5 \mathrm{~g} / \mathrm{kg}$; essential oils - basal diet supplemented with a mixture of carvacrol, cinnamaldehyde and capsicum oleoresin at a dose of $0.15 \mathrm{~g} / \mathrm{kg}$; SEM - standard error of the mean; ${ }^{\mathrm{a}-\mathrm{d}}-$ means within the same row with different superscripts are significantly different at $P<0.05$ 
Table 6. Effect of dietary supplementation of examined synbiotics, organic acids and essential oils on intestinal microbiota of the Japanese quail at 42 day of age

\begin{tabular}{lcccc}
\hline Indices & Treatments $^{1}$ & & & \\
\cline { 2 - 5 } & control & synbiotics & organic acids & essential oils \\
\hline Total bacterial count, CFU & $30.7 \times 10^{6}$ & $20.3 \times 10^{6}$ & $12.7 \times 10^{6}$ & $\mathrm{ND}$ \\
Escherichia coli, CFU & $23 \times 10^{6}$ & $6.2 \times 10^{6}$ & $\mathrm{ND}$ & \\
Lactobacillus spp., CFU & $4.4 \times 10^{6}$ & $5.3 \times 10^{6}$ & $5.1 \times 10^{6}$ & $6.1 \times 10^{6}$ \\
\hline
\end{tabular}

${ }^{1}$ treatments: control - un-supplemented basal diet; synbiotics - basal diet supplemented with a mixture of live Saccharomyces cerevisiae, Bacillus spp. and their cell wall extracts, in addition to $\beta$-glucan and mannan-oligosaccharides at a dose of $1 \mathrm{~g} / \mathrm{kg}$; organic acids - basal diet supplemented with a mixture of formic and propionic acids at a dose of $0.5 \mathrm{~g} / \mathrm{kg}$; essential oils - basal diet supplemented with a mixture of carvacrol, cinnamaldehyde and capsicum oleoresin at a dose of $0.15 \mathrm{~g} / \mathrm{kg}$; CFU - colony-forming units, ND - non-detectable

\section{Discussion}

The beneficial effect of essential oils mixtures on growth performance is mainly regarded to the presence of some active components, such as thymol, carvacrol, cinnamaldehyde, eugenol and capsaicinoids, which may improve digestion process, stimulate the secretion of digestive enzymes and increase the nutrients bioavailability by the host (Sengül et al., 2008; Bravo et al., 2014). Additionally, Mehdipour et al. (2013) reported that cinnamon essential oil (rich in cinnamaldehyde) has antioxidant properties as well as antimicrobial and antifungal activity against pathogens found in the intestine of birds, which could improve the performance of quails fed diets supplemented with this essential oil. While the role of formic and propionic acids in promoting growth performance could be as acidifiers in the crop media inhibiting the growth of pathogenic bacteria; so that such organic acids reduce the competition between pathogenic bacteria and the host for nutrients that increasing the profitability and utilization of dietary nutrients by animal (Hassan et al., 2010; Fouladi et al., 2018).

On the other hand, blood parameters could be used as an indicator of the physiological and health status as well as the welfare condition of birds (Ognik and Sembratowicz, 2012). The higher RBCs count and haemoglobin concentration may be due to changes in the $\mathrm{pH}$ value of the alimentary tract caused by beneficial bacteria colonization in the gut, which may improve iron salt absorption from the small intestine leading to intensification of erythropoiesis (Mirza, 2018).

The high globulin concentrations associated with growth promoters' treatments may support the finding of higher immune status of birds fed diets supplemented with a commercial organic acids and essential oils growth promoter containing citric acid, calcium butyrate, calcium lactate, calcium fumarate, cinnemalehyde, thymol and carvacrol (El-Shenway and Ali, 2016). In accordance with the obtained results of protein profile, Oleforuh-Okoleh et al. (2015) reported that there was a significant increase in the total protein, albumin and globulin of broilers fed diets treated by ginger or garlic extracts when compared with the control group.

The insignificant difference of blood glucose value among the experimental groups may ensure normal glucose metabolism for all experimental groups.

The increased total lipids and triglyceride levels could be explained as essential oils mixture containing carvacrol, cinnamaldehyde and capsicum oleoresin as well as mixture of organic acids such as formic and propionic acids used as growth promoters improve nutrients absorption and utilization, which may positively affect energy and lipid metabolism as well as lipoprotein synthesis (Fouladi et al., 2014). Firstly, muscle cells uptake the absorbed energy in presence of amino acids which consequently increases the tissue syntheses, then the excess of energy and lipid is converted to fat and stored as triglycerides or neutral lipids in the adipose tissues (Ghazi et al., 2012). So, reducing the level of such growth promoter products below the recommended studied levels could be better for achieving the optimal performance without excessive utilization of energy and lipids. This obtained finding would also suggest a slight reduction in metabolizable energy for quail diets supplemented with either examined essential oils or organic acids in order to avoid the undesirable lipid conversion, which may accordingly reduce feeding cost.

The insignificant effect of the studied growth promoters on blood serum uric acid and creatinine concentrations for the experimental treatments may reveal that the studied growth promoters used in the present experiment were safe for birds and had no dangerous effects on kidney functions of treated birds (Ahmad et al., 2018).

The higher values of abdominal fat recorded for the examined growth promoters' treatments is expected as such experimental groups had higher 
plasma total lipids and triglyceride levels which eventually deposited as neutral lipids in the adipose tissues (mainly abdominal fat tissues). In this regard, Ocak et al. (2008) reported that phenolic compounds present in thyme leaves (thymol, carvacrol and $\gamma$-terpipene) increased $(P<0.05)$ the abdominal fat pad for broilers at 42 day of age.

Intestinal morphology is the main indicator of gut health. The functional status of the small intestine is characterized in part by villus height and width in addition to their density in a constant intestine area. Lengthening of villi observed in the present study for essential oils and organic acids groups may increase total luminal villus absorptive area, which subsequently might result in satisfactory digestive enzyme action and higher absorption of nutrients at the villus surface (Oliveira et al., 2008). Along the same line, previous researchers have reported an improvement in villus histomorphology of birds treated with either formic and propionic acids or a combination of rosemary oil and Nigella sativa oil (Paul et al., 2007; Aziza et al., 2019). The favourable effects of the studied growth promoters on bacterial populations of the intestine may be explained as carvacrol, cinnamaldehyde and capsicum oleoresin have antimicrobial and antifungal activity against pathogens, in addition formic and propionic acids produce acidic environment in the gut that favouring the development of beneficial bacteria (e.g., Lactobacilli) and inhibiting the replication of E. coli, Salmonella and other Gram-negative bacteria, which may promote poultry growth (Mehdipour et al., 2013; Sultan et al., 2015).

\section{Conclusions}

Dietary supplementation of growing Japanese quails with either essential oils (a mixture of carvacrol, cinnamaldehyde and capsicum oleoresin) or organic acids (a mixture of formic and propionic acids) enhanced the health status of the intestine, through improving villus properties and controlling pathogens, which was positively reflected on physiological status and overall growth performance. However, the mixture of Saccharomyces cerevisiae, Bacillus spp. and their cell wall extracts, in addition to $\beta$-glucan and mannan-oligosaccharides as synbiotics had moderate beneficial effects on the studied traits. Summarizing, such organic compounds are recommended to include in quails' diets from the second week of age up to the marketing age in order to obtain better performance of growing quails.

\section{Conflict of interest}

The authors declare that there is no conflict of interest.

\section{References}

Abd-Allah SH.M.S., Abdel-Raheem SH.M., 2012. Effect of dietary mannan oligosaccharides supplementation level on the carcass characteristics, meat quality and intestinal microbial ecology of Japanese quail (Coturnix japonica). Assiut Vet. Med. J. 58, 41-49, https://doi.org/10.21608/ avmj.2012.172152

Abd El-Hack M.E., Alagawany M., Abdel-Moneim A.-M.E., Mohammed N.G., Khafaga A.F., Bin-Jumah M., Othman S.I., Allam A.A., Elnesr S.S., 2020. Cinnamon (Cinnamomum zeylanicum) oil as a potential alternative to antibiotics in poultry. Antibiotics 9 , 210, https://doi.org/10.3390/antibiotics9050210

Ahmad E.A.M., Abdel-Kader I.A., Abdel-Wahab A.A., 2018. Organic acids as potential alternate for antibiotic as growth promoter in Japanese quail. Egypt. Poult. Sci. 38, 359-373

Akanbi O.M., Kabir M., 2019. Nutrient requirements and management of Japanese quails (Cortunix cortunix japonica): A review. Agric. Rev. 40, 534-553

Aziza A.E., Abdelhamid F.M., Risha E.F., Elsayed M.M., Awadin W.F. 2019. Influence of Nigella sativa and rosemary oils on growth performance, biochemical, antioxidant and immunological parameters, and pathological changes in Japanese quail challenged with Escherichia coli. J. Anim. Feed Sci. 28, 354-366, https://doi.org/10.22358/jafs/114239/2019

Bancroft J.D., Layton C., 2013. The hematoxylin and eosin. In: S. Kim Suvarna, C. Layton, J.D. Bancroft (Editors). Bancroft's Theory Practice of Histological Techniques. $7^{\text {th }}$ Edition. Churchill Livingstone. London (UK), pp. 173-186, https://doi. org/10.1016/b978-0-7020-4226-3.00010-x

Baurhoo B., Phillip L., Ruiz-Feria C.A., 2007. Effects of purified lignin and mannan oligosaccharides on intestinal integrity and microbial populations in the ceca and litter of broiler chickens. Poult. Sci. 86, 1070-1078, https://doi.org/10.1093/ ps/86.6.1070

Bravo D., Pirgozliev V., Rose S.P., 2014. A mixture of carvacrol, cinnamaldehyde and capsicum oleoresin improves energy utilization and growth performance of chickens fed maizebased diet. J. Anim. Sci. 92, 1531-1536, https://doi. org/10.2527/jas.2013-6244

Collett S.R., 2004. Controlling gastrointestinal disease to improve absorptive membrane integrity and optimize digestion efficiency. In: L.A. Tucker, J.A. Taylor-Pickard (Editors). Interfacing Immunity, Gut Health and Performance. Nottingham University Press, Nottingham (UK), pp. 77-91

Cross D.E., McDevitt R.M., Hillman K., Acamovic T., 2007. The effect of herbs and their associated essential oils on performance, dietary digestibility and gut microflora in chickens from 7 to 28 days of age. Br. Poult. Sci. 48, 496-506, https://doi. org/10.1080/00071660701463221

Curry B.B. III, 2009. Animal models used in identifying genderrelated differences. Int. J. Toxicol. 20, 153-160, https://doi. org/10.1080/109158101317097737

Duncan D.B., 1955. Multiple range and multiple F tests. Biometrics 11, 1-42, https://doi.org/10.2307/3001478

El-Shenway A.M., Ali G.I.E., 2016. Effect of some organic acids and essential oils as feed additives on growth performance, immune response and carcass quality of Japanese quail. Alex. J. Vet. Sci. 51, 68-77, https://doi.org/10.5455/ajvs.242100 
Fascina V.B., Sartori J.R., Gonzales E., de Carvalho F.B., de Souza I.M.G.P., Polycarpo G.V., Stradiotti A.C., Pelícia V.C., 2012. Phytogenic additives and organic acids in broiler chicken diets. Rev. Bras. Zootec. 41, 2189-2197, https://doi. org/10.1590/S1516-35982012001000008

Feldman B.V., Zinkl J.G., Jain N.C., 2000. Schalm's Veterinary Hematology. Lippincott Williams and Wilkins. Philadelphia, PA (USA)

Fouladi P., Ebrahimnezhad Y., Aghdam Shahryar H., Maheri S.N., Ahmadzadeh A., 2014. Effects of organic acids supplement on performance and gut parameters in male Japanese quail (Coturnix coturnix). Biol. Forum - Int. J. 6, 102-109

Fouladi P., Ebrahimnezhad Y., Aghdam Shahryar H., Maheri N., Ahmadzadeh A., 2018. Effects of organic acids supplement on performance, egg traits, blood serum biochemical parameters and gut microflora in female Japanese quail (Coturnix coturnix japonica). Braz. J. Poult. Sci. 20, 133-144, https://doi.org/10.1590/1806-9061-2016-0375

Ghazi Sh., Habibian M., Moeini M.M., Abdolmohammad A.R., 2012. Effects of different levels of organic and inorganic chromium on growth performance and immunocompetence of broilers under heat stress. Biol. Trace Elem. Res. 146, 309-317, https://doi.org/10.1007/s12011-011-9260-1

Goodarzi Boroojeni F., Vahjen W., Mader A., Knorr F., Ruhnke I., Röhe I., Hafeez A., Villodre C., Männer K., Zentek J., 2014. The effects of different thermal treatments and organic acid levels in feed on microbial composition and activity in gastrointestinal tract of broilers. Poult. Sci. 93, 1440-1452, https://doi.org/10.3382/ps.2013-03763

Griggs J.P., Jacob J.P., 2005. Alternatives to antibiotics for organic poultry production. J. Appl. Poult. Res. 14, 750-756, https:// doi.org/10.1093/japr/14.4.750

Hassan H.M.A., Mohamed M.A., Youssef A.W., Hassan E.R., 2010. Effect of using organic acids to substitute antibiotic growth promoters on performance and intestinal microflora of broilers. Asian-Australas. J. Anim. Sci. 23, 1348-1353, https://doi.org/10.5713/ajas.2010.10085

Incharoen T., Yamauchi K.-e., Erikawa T., Gotoh H., 2010. Histology of intestinal villi and epithelial cells in chickens fed low-crude protein or low-crude fat diets. Ital. J. Anim. Sci. 9, 429-434, https://doi.org/10.4081/ijas.2010.e82

Jamroz D., Orda J., Kamel C., Wiliczkiewicz A., Wertelecki T., Skorupińska J., 2003. The influence of phytogenic extracts on performance, nutrient digestibility, carcass characteristics, and gut microbial status in broiler chickens. J. Anim. Feed Sci. 12, 583-596, https://doi.org/10.22358/jafs/67752/2003

Krauze M., Cendrowska-Pinkosz M., Matuseviciius P., Stępniowska A., Jurczak P., Ognik K., 2021. The effect of administration of a phytobiotic containing cinnamon oil and citric acid on the metabolism, immunity, and growth performance of broiler chickens. Animals 11, 399, https://doi.org/10.3390/ ani11020399

Lin J., Hunkapiller A.A., Layton A.C., Chang Y.-J., Robbins K.R., 2013. Response of intestinal microbiota to antibiotic growth promoters in chickens. Foodborne Pathog. Dis. 10, 331-337, https://doi.org/10.1089/fpd.2012.1348

Mehdipour Z., Afsharmanesh M., Sami M., 2013. Effects of dietary synbiotic and cinnamon (Cinnamomum verum) supplementation on growth performance and meat quality in Japanese quail. Livest. Sci. 15, 152-157, https://doi. org/10.1016/j.livsci.2013.03.014
Mirza R.A., 2018. Probiotics and prebiotics for the health of poultry. In: D. Di Gioia, B. Biavati (Editors). Probiotics and Prebiotics in Animal Health and Food Safety. Springer. Cham (Swizerland), pp. 127-154, https://doi.org/10.1007/978-3-319-71950-4_5

Moniello G., Bovera F., Solinas I.L., Piccolo G., Pinna W., Nizza A., 2005. Effect of age and blood collection site on the metabolic profile of ostriches. S. Afr. J. Anim. Sci. 35, 268-272, https:// doi.org/10.4314/sajas.v35i4.3970

Ocak N., Erener G., Burak Ak F., Sungu M., Altop A., Ozmen A., 2008. Performance of broilers fed diets supplemented with dry peppermint (Mentha piperita L.) or thyme (Thymus vulgaris L.) leaves as growth promoter source. Czech J. Anim. Sci. 53, 169-175, https://doi.org/10.17221/373-CJAS

Ognik K., Sembratowicz I., 2012. Effect of Aloe-plus preparation supplement on hematological and immunological blood parameters and performance of turkey hens. Turk. J. Vet. Anim. Sci. 36, 491-498, https://doi.org/10.3906/vet-1009-465

Oleforuh-Okoleh V.U., Ndofor-Foleng H.M., Olorunleke S., Uguru J., 2015. Evaluation of growth performance, haematological and serum biochemical response of broiler chickens to aqueous extract of ginger and garlic. J. Agric. Sci. 7, 167-173, https:// doi.org/10.5539/jas.v7n4p167

Oliveira M.C., Rodrigues E.A., Marques R.H., Gravena R.A., Guandolini G.C., Moraes V.M.B., 2008. Performance and morphology of intestinal mucosa of broilers fed mannanoligosaccharides and enzymes. Arq. Bras. Med. Vet. Zootec. 60, 442-448, https://doi.org/10.1590/S0102-09352008000200025

Paul K.S., Halder G., Mondal M.K., Samanta G., 2007. Effect of organic acid salt on the performance and gut health of broiler chicken. J. Poult. Sci. 44, 389-395, https://doi.org/10.2141/ jpsa.44.389

Provan D., Singer C.R.J., Baglin T., Lilleyman J. (Editors), 2004. Oxford Handbook of Clinical Haematology. $2^{\text {nd }}$ Edition. Oxford University Press. New York, NY (USA)

Rageb S.M.M., Abd-Allah E.A., Abou Khalil N.S., Abdel-Maksoud F.M., Mahmoud U.T., 2018. Effects of mannan-oligosaccharide and $\beta$-glucan prebiotic on the brain oxidant/antioxidant balance in broilers under natural Egyptian summer conditions. Egypt. Acad. J. Biol. Sci. (B. Zoo.) 10, 35-46, https://doi. org/10.21608/eajbsz.2018.13428

Sengül T., Yurtseven S., Cetin M., Kocyigit A., Sögüt B., 2008. Effect of thyme ( $T$. vulgaris) extracts on fattening performance, some blood parameters, oxidative stress and DNA damage in Japanese quails. J. Anim. Feed Sci. 17, 608-620, https://doi. org/10.22358/jafs/66689/2008

Sohail M.U., Hume M.E., Byrd J.A., Nisbet D.J., ljaz A., Sohail A., Shabbir M.Z., Rehman H., 2012. Effect of supplementation of prebiotic mannanoligosaccharides and probiotic mixture on growth performance of broilers subjected to chronic heat stress. Poult. Sci. 91, 2235-2240, https://doi.org/10.3382/ ps.2012-02182

Sultan A., Ullah T., Khan S., Khan R.U., 2015. Effect of organic acid supplementation on the performance and ileal microflora of broiler during finishing period. Pak. J. Zool. 47, 635-639

Talazadeh F., Naghavi M., Mayahi M., Gharibi D., 2017. The effect of Antibiofin ${ }^{\circledR}$ on intestinal bacterial population in broiler chickens. J. Zoonotic. Dis. 2(1), 9-13 